\title{
Rapid response of Nelson's syndrome to pasireotide in radiotherapy-naive patient
}

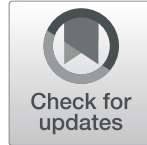

Xin $\mathrm{He}^{1}$ and Joanna L. Spencer-Segal ${ }^{1,2^{*}}$

\begin{abstract}
Background: Nelson's syndrome is a well-described complication following bilateral adrenalectomy for management of Cushing's disease. There is no consensus on optimal management of Nelson's syndrome, characterized by the triad of pituitary corticotroph adenoma growth, elevated serum adrenocorticotropic hormone, and skin hyperpigmentation. Medical therapy with a variety of drug classes have been studied. One potentially promising drug already approved for Cushing's disease is pasireotide, a somatostatin analog with affinity for multiple somatostatin receptors, including subtype 5, the most highly expressed receptor on corticotroph tumors.

Case presentation: A 24-year-old female was diagnosed with Cushing's disease with initial ACTH levels around $700-800 \mathrm{pg} / \mathrm{mL}$. She underwent transsphenoidal surgery without remission, followed by bilateral adrenalectomy. Over the subsequent 3 years, the patient developed skin hyperpigmentation, recurrent elevations of ACTH, and tumor recurrence requiring two additional transsphenoidal surgeries. After her third transsphenoidal resection, ACTH normalized, no residual tumor was seen on radiology, and the patient's skin hyperpigmentation improved. She then had an uncomplicated full-term pregnancy, during which ACTH levels remained within normal limits. One month after delivery, ACTH levels began rising to a peak at 5,935 pg/mL. Imaging revealed two new bilateral pituitary adenomas, measuring $14 \mathrm{~mm}$ on the left, and $7 \mathrm{~mm}$ on the right. She was then started on pasireotide. After two months of therapy, ACTH decreased to $609 \mathrm{pg} / \mathrm{mL}$, and repeat pituitary MRI showed interval decrease in size of both pituitary adenomas to $13 \mathrm{~mm}$ on the left and $6 \mathrm{~mm}$ on the right.

Conclusion: We report the protracted course of a young female with several recurrences of Nelson's syndrome following bilateral adrenalectomy and multiple transsphenoidal surgeries, who ultimately responded to pasireotide. Unique features of her case not described previously are the response to pasireotide in a radiotherapy-naive patient, as well as the rapid radiologic response to therapy. Her history illustrates the unresolved challenges of Nelson's syndrome and the continued need for additional studies to identify optimal management.
\end{abstract}

Keywords: Nelson's syndrome, Cushing's disease, Pasireotide, Somatostatin analog

\footnotetext{
*Correspondence: sjoanna@med.umich.edu

${ }^{1}$ Department of Internal Medicine, Division of Metabolism, Endocrinology \& Diabetes, University of Michigan, 1500 East Medical Center Drive, Ann Arbor, Ml 48109, USA

${ }^{2}$ Michigan Neuroscience Institute, University of Michigan, 205 Zina Pitcher PI, Ann Arbor, Ml 48109, USA
}

(c) The Author(s). 2020 Open Access This article is licensed under a Creative Commons Attribution 4.0 International License, which permits use, sharing, adaptation, distribution and reproduction in any medium or format, as long as you give appropriate credit to the original author(s) and the source, provide a link to the Creative Commons licence, and indicate if changes were made. The images or other third party material in this article are included in the article's Creative Commons licence, unless indicated otherwise in a credit line to the material. If material is not included in the article's Creative Commons licence and your intended use is not permitted by statutory regulation or exceeds the permitted use, you will need to obtain permission directly from the copyright holder. To view a copy of this licence, visit http://creativecommons.org/licenses/by/4.0/. The Creative Commons Public Domain Dedication waiver (http://creativecommons.org/publicdomain/zero/1.0/) applies to the data made available in this article, unless otherwise stated in a credit line to the data. 


\section{Background}

Nelson's syndrome is a well-described complication following bilateral adrenalectomy for management of Cushing's disease. While the preferred first-line management of Cushing's disease is surgical resection of the underlying corticotroph tumor, bilateral adrenalectomy can be an effective alternative when the underlying lesion is unidentifiable, unresectable, or refractory to surgery. In $88-100 \%$ of cases, adrenalectomy results in successful remission of Cushing's disease and control of hypercortisolism $[1,2]$. However, studies of surgical cohorts indicate that $15 \%$ to $47 \%$ of patients experience growth of pituitary corticotroph adenomas, elevated serum adrenocorticotropic hormone (ACTH), and skin hyperpigmentation [1, 3-7]; these three features are considered the triad of Nelson's syndrome.

The clinical presentation and time course of Nelson's syndrome can be highly variable, ranging from mild hyperpigmentation occurring 6 months after adrenalectomy, to severe neurologic symptoms related to tumor mass effect developing after two decades $[1,5,3,6-8]$. There is currently no consensus on the management of Nelson's syndrome. Management options include observation, surgical resection, pituitary radiotherapy, and medical treatment.

Medical therapy with a variety of drug classes have been studied with inconsistent effectiveness [9-11]. One potentially promising drug is pasireotide, a somatostatin analog with affinity for somatostatin-receptor subtypes $1,2,3$, and 5 [12]. Pasireotide was found to inhibit ACTH production in vitro and in vivo [13], ultimately leading to its FDA-approval for treatment of Cushing's disease in 2012 [14]. Here, we present a case of recurrent Nelson's syndrome with rapid and impressive response to pasireotide in a radiotherapy-naïve patient.

\section{Case presentation}

A 24-year-old female presented to an outside medical center and was diagnosed with ACTH-dependent Cushing's disease due to a $5 \mathrm{~mm}$ pituitary microadenoma located in the midline inferior portion of the pituitary. At the initial diagnosis, ACTH levels were around 700$800 \mathrm{pg} / \mathrm{mL}$ (Fig. 1). She underwent transsphenoidal surgery without remission: postoperative cortisol was documented as $18 \mathrm{mcg} / \mathrm{dL}$ with ACTH $118 \mathrm{pg} / \mathrm{mL}$, prompting eventual bilateral adrenalectomy three months later.

Over the subsequent year, the patient's ACTH level gradually increased up to a peak of $1300 \mathrm{pg} / \mathrm{mL}$. Repeat pituitary imaging revealed a $10 \mathrm{~mm}$ pituitary adenoma in the same location as her initial microadenoma, prompting a second transsphenoidal surgery. Pituitary MRI completed six months after her second transsphenoidal surgery showed postsurgical changes in the posterior superior nasal septum without evidence of a sellar mass. However, postoperative ACTH levels ranged 200$300 \mathrm{pg} / \mathrm{mL}$.

Over the subsequent 2 years following her second transsphenoidal surgery, the patient noted progressive darkening of her skin and recurrent episodes of sinusitis. Repeat pituitary MRI revealed a $5 \mathrm{~mm}$ microadenoma, again in the midline inferior region of the pituitary gland (Fig. 2a). Labs included ACTH 855 pg/mL with cortisol $18 \mathrm{mcg} / \mathrm{dL}$. The patient was referred to our clinic at this point. On our evaluation, we noted hyperpigmentation of her lips, axillae, and adrenalectomy scars. After discussion of the treatment options, the patient elected to undergo a third transsphenoidal surgery, and this was completed without complications (Fig. 2b). The resected tumor was found to be an adenoma staining positive for

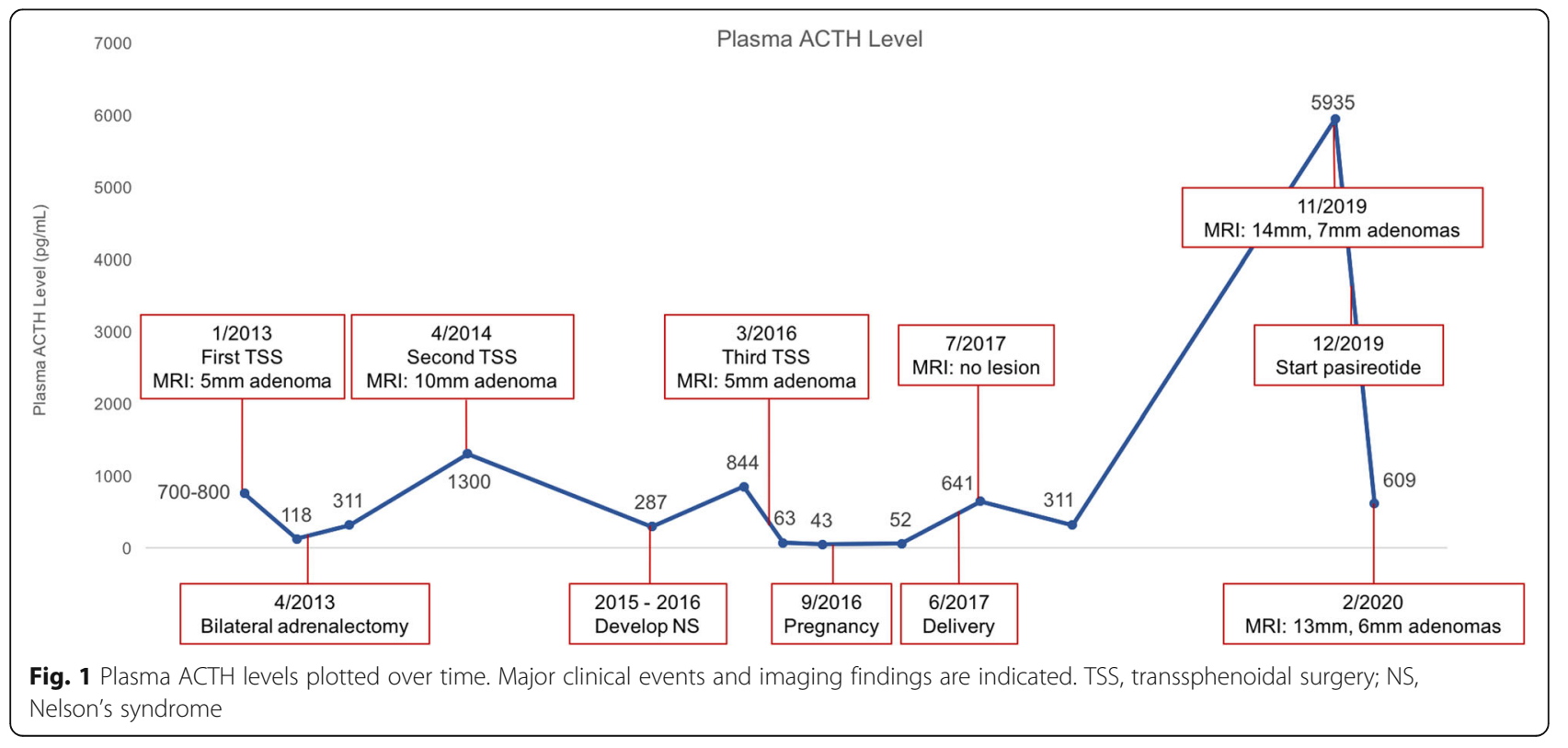




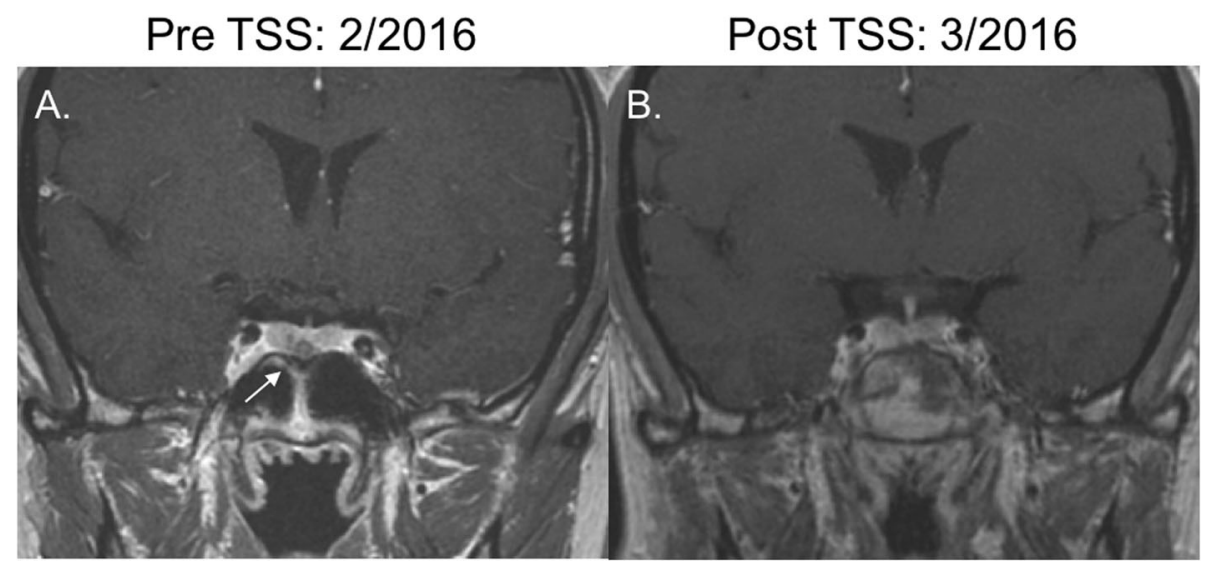

Fig. 2 Coronal T1-weighted MRI scans. a. February 2016: Inferior pituitary 5 mm lesion indicative of recurrence of Nelson's syndrome. Imaging completed prior to third transsphenoidal surgery. b. March 2016: Resolution of pituitary lesion after third transsphenoidal surgery

synaptophysin and ACTH with an elevated Ki67 proliferation index of $8 \%$. Postoperatively, ACTH normalized to a nadir of $43 \mathrm{pg} / \mathrm{mL}$. The patient's skin hyperpigmentation also improved. She had no evidence of developing hypopituitarism after surgery: TSH, free T4, and sodium levels remained normal, and menses occurred regularly.

Six months after her third transsphenoidal surgery, the patient conceived spontaneously. ACTH during her second trimester was in the upper end of normal range, $52 \mathrm{pg} / \mathrm{mL}$. The patient vaginally delivered a healthy boy at 39 weeks gestation without complications. ACTH checked one month after delivery was elevated at $641 \mathrm{pg} / \mathrm{mL}$. The patient again developed skin hyperpigmentation. Pituitary MRI did not show any lesions. Radiation therapy and medical therapy were discussed with the patient, but treatment was postponed as she was breastfeeding. At follow-up nine months postpartum, the patient had stopped breastfeeding. ACTH was $311 \mathrm{pg} / \mathrm{mL}$ and surveillance was continued.

Over 3 years after her third transsphenoidal surgery, the patient returned for follow-up with progressive skin darkening. ACTH rose to $5,935 \mathrm{pg} / \mathrm{mL}$. Pituitary MRI revealed interval enlargement of the pituitary gland, as well as development of two new nonenhancing adenomas, $14 \mathrm{~mm}$ on the left extending to midline, $7 \mathrm{~mm}$ on the right (Fig. 3a and b). Treatment options of transsphenoidal surgery, radiation therapy, and pasireotide were discussed. The patient elected to start pasireotide. She had already undergone placement of an intrauterine device for contraception.

After 1 month of taking short-acting pasireotide $0.3 \mathrm{mg}$ twice daily, the patient reported side effects of mild diarrhea and nausea. She also developed frequent palpitations, for which a Holter monitor was ordered and was unrevealing. She noted improvement in her skin hyperpigmentation, notably that she was able to better visualize her pre-existing tattoos. ACTH level two months after starting pasireotide decreased to $609 \mathrm{pg} /$ $\mathrm{mL}$ (Fig. 2). Repeat pituitary MRI also showed slight interval decrease in size of both pituitary adenomas to $13 \mathrm{~mm}$ on the left extending to midline, $6 \mathrm{~mm}$ on the right (Fig. 3c and d). The pasireotide dose was increased to $0.6 \mathrm{mg}$ twice daily. Blood work completed several months after starting pasireotide showed serum glucose

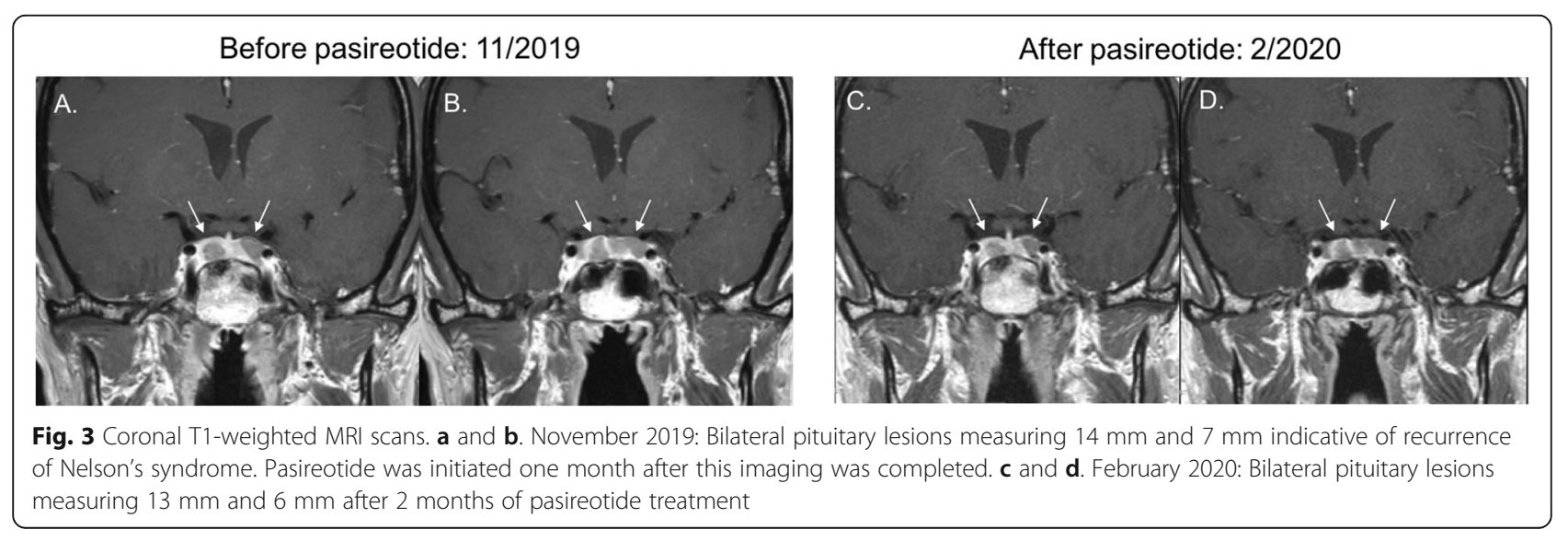


levels remaining in normal range with glycated hemoglobin level of $5.2 \%$.

\section{Discussion and conclusions}

More than half a century after Dr. Don Nelson first described the eponymous condition [15], Nelson's syndrome remains challenging to manage. Current strategies include observation, surgical resection, prophylactic and treatment radiotherapy, and medical management. After bilateral adrenalectomy for treatment of Cushing's disease, predicting which of the $15-47 \%$ of the patients will develop Nelson's syndrome is difficult $[1,3-7]$. Risk factors associated with increased incidence of Nelson's syndrome are residual pituitary tumor seen on imaging prior to adrenalectomy $[6,16-18]$ and elevated ACTH 1 year after adrenalectomy $[3,6,19]$. Pregnancy is not associated with accelerated ACTH rise or corticotroph tumor growth [20]. There is inconclusive and/or conflicting data on the association of other risk factors, such as age [3, 21-23], duration of Cushing's disease prior to adrenalectomy [1, 2, 18, 23], tumor proliferation index $[24,25]$, elevated urinary free cortisol prior to surgery $[1,6,18]$, and inadequate glucocortiocoid replacement postoperatively $[1,26,27]$. Possible contributing risk factors in this patient's case include her young age, ACTH level of more than 1,300 ng/dL within a year after adrenalectomy, and elevated Ki67 proliferation index; we also cannot exclude the possibility of residual pituitary tumor prior to adrenalectomy, as we do not have imaging from that time. Consistent with existing data in radiotherapy-naïve women [20], the patient's Nelson's syndrome was controlled and did not cause complications during pregnancy.

Several studies have evaluated the efficacy of prophylactic pituitary radiotherapy after adrenalectomy. Two retrospective reviews found pituitary radiotherapy to be associated with lower incidence of Nelson's syndrome: one cohort found that $50 \%$ of patients who did not receive radiotherapy developed Nelson's syndrome compared to $0 \%$ in the cohort that did [17]; another study found radiotherapy was associated with $25 \%$ incidence of Nelson's syndrome compared to $50 \%$ in the absence of radiotherapy [16]. However, several other studies did not find this association $[18,19,28]$. While some centers administer prophylactic radiotherapy in all patients following bilateral adrenalectomy who have residual pituitary tissue [29], this is not universal practice and was not done in this case.

Administration of radiotherapy after onset of Nelson's syndrome has also been studied, with stereotactic radiosurgery as the most common intervention [9]. Several studies have found that stereotactic radiosurgery is associated with decreasing Nelson's syndrome tumor volume and/or serum ACTH levels, through response to therapy has been widely variable, with reported long-term remission rates ranging from 14 to $92 \%$ [30-35]. Complications of hypopituitarism and partial or permanent cranial nerve damage are seen in $7-40 \%, 20 \%$, and $5-7 \%$ of patients, respectively [31,35]. To prevent these potential complications in a young woman, radiotherapy was avoided in our patient.

When feasible, surgical resection of the Nelson's syndrome tumor is commonly recommended. Reported success rates of pituitary surgery varies widely from 10 to $70 \%$ [11, 36-38]. Higher rates of remission have been associated with smaller tumors, adjuvant radiotherapy, and absence of tumor invasion into the dura mater [11, 36, 37]. The most common complications are hypopituitarism, cerebrospinal fluid leak, and meningitis occurring in up to $69 \%, 15 \%$, and $8 \%$ of postoperative patients, respectively [38-40]. Patients requiring multiple pituitary surgeries, as was the case in our patient, are not uncommon in the literature [11, 26, 37].

Various classes of medical therapy have been explored but data remain limited. Several case reports found that cabergoline provided long-term control of Nelson's syndrome, but bromocriptine did not [41-43]. Two case reports have also described the use of temazolomide in aggressive Nelson's syndrome tumors to successfully achieve significant decreases in tumor size and ACTH level $[44,45]$. Rosiglitazone has been studied, as peroxisome proliferator-activated $\gamma$ receptors are expressed in corticotroph adenomas; however, several small prospective trials showed no ACTH response to rosiglitazone [46-48]. Valproic acid has also been evaluated due to its inhibition of $\gamma$-aminobutyric acid, thereby reducing production of corticotropin-releasing hormone by the hypothalamus; however, several small prospective and retrospective studies of valproic acid alone or in conjunction with radiotherapy and surgery have not found consistent decreases in tumor size and ACTH level $[17,49,50]$.

Octreotide and pasireotide are somatostatin analogs that have been trialed with encouraging results in Nelson's syndrome. The first evidence for the use of this drug class was noted when somatostatin infused in a small group of Nelson's patients decreased their serum ACTH levels by $40 \%$ to $71 \%$ [51]. Several case series and case reports have found biochemical and symptomatic improvement with octreotide [52-54], with reported decreases in ACTH levels by $54 \%$ to $70 \%$. Another case report described more impressive results in a patient with history of Nelson's syndrome refractory to multiple pituitary surgeries and radiotherapy, for whom pasireotide decreased serum ACTH from $42,710 \mathrm{pg} / \mathrm{mL}$ to $4,272 \mathrm{pg} /$ $\mathrm{mL}$, along with decrease in tumor size and improvement in hyperpigmentation; the patient did also develop the known side effect of hyperglycemia [55]. Corticotroph tumors have been found to express somatostatin receptors (SST) 1, 2, 4, and 5, but with the highest expression of SST 5 [56]. Octreotide binds most strongly to SST 2 
and with lower affinity to SST 5 , whereas pasireotide binds to SST 1, 2, 3, and 5, with high affinity [12]. This differential binding affinity for SST 5 is conjectured to be the reason for improved response of Cushing's disease [57], and perhaps of Nelson's syndrome as well, to pasireotide compared to octreotide.

Most recently, a prospective study of pasireotide twice daily injection for four weeks followed by long-acting release formulation for 24 weeks recruited eight patients with Nelson's syndrome [58]. Six patients overall had partial or complete biochemical response, without conclusive changes in pituitary tumor size or skin pigmentation. Due to side effects including gastrointestinal distress and hyperglycemia, only half (four) of the patients completed the study. Notably, all three patients who had a complete response also had history of receiving radiotherapy prior to study enrollment. The authors suggest that studies of larger cohorts and longer study duration, while balancing the impact of side effects, are needed to better understand the role of pasireotide for management of Nelson's syndrome.

Unique features of our case not described previously are the response to pasireotide in a radiotherapy-naive patient, as well as the rapid radiologic response to therapy. Due to her young age, radiotherapy had been avoided in management, whereas all existing reports of patients with sustained response to pasireotide received prior radiotherapy. Furthermore, radiologic improvement was observed after just two months of pasireotide therapy; radiologic improvement was noted on the ninemonth follow-up imaging in the prior case report [55], but not seen in the prospective trial [58]. Thus, this is the first report of a radiotherapy-naïve patient with $\mathrm{Nel}$ son's syndrome who has responded to pasireotide.

In summary, we report the protracted course of a young female with Nelson's syndrome with recurrence after multiple transsphenoidal surgeries, who ultimately responded to pasireotide. Like the participants in the prospective study, our patient similarly has experienced a number side effects, and it remains to be seen whether she will tolerate pasireotide therapy long term. Her history illustrates the unresolved challenges of Nelson's syndrome and the continued need for additional studies to identify optimal management.

\section{Abbreviations \\ ACTH: Adrenocorticotropic hormone; NS: Nelson's syndrome; SST: Somatostatin receptor; TSS: Transsphenoidal surgery; TSH: Thyroid stimulating hormone}

\section{Acknowledgements}

We thank Ariel L. Barkan for his clinical consultation on this case and his suggestion to report this case.

\section{Authors' contributions}

All authors have drafted the work or substantively revised it. All authors have read and approved the final manuscript.

\section{Funding}

$\mathrm{XH}$ is supported by grant T32DK07245 from the National Institutes of Diabetes and Digestive and Kidney Diseases. JSS is supported by grant MH116267 from the National Institute of Mental Health.

\section{Availability of data and materials}

Not applicable.

Ethics approval and consent to participate

Not applicable.

\section{Consent for publication}

The patient consented to publication of her medical history.

\section{Competing interests}

The authors declare that they have no competing interests.

Received: 18 August 2020 Accepted: 25 October 2020

Published online: 07 November 2020

\section{References}

1. Nagesser SK, van Seters AP, Kievit J, Hermans J, Krans HM, van de Velde CJ. Long-term results of total adrenalectomy for Cushing's disease. World J Surg. 2000;24(1):108-13.

2. Kelly WF, MacFARLANE IA, Longson D, Davies D, Sutcliffe H. Cushing's Disease Treated by Total Adrenalectomy: Long-term Observations of 43 Patients. QJM Int J Med. 1983;52(2):224-31.

3. Assié $G$, Bahurel $H$, Coste J, Silvera $S$, Kujas M, Dugué M-A, et al. Corticotroph Tumor Progression after Adrenalectomy in Cushing's Disease: A Reappraisal of Nelson's Syndrome. J ClinEndocrinolMetab. 2007:92(1):172-9.

4. Ritzel K, Beuschlein F, Mickisch A, Osswald A, Schneider HJ, Schopohl J, et al. Outcome of Bilateral Adrenalectomy in Cushing's Syndrome: A Systematic Review. J ClinEndocrinolMetab. 2013;98(10):3939-48.

5. Invitti C, Giraldi FP, De Martin M, Cavagnini F. Diagnosis and Management of Cushing's Syndrome: Results of an Italian Multicentre Study. J ClinEndocrinolMetab. 1999;84(2):440-8.

6. Pereira MAA, Halpern A, Salgado LR, Mendonça BB, Nery M, Liberman B, et al. A study of patients with Nelson's syndrome. ClinEndocrinol (Oxf). 1998; 49(4):533-9.

7. Favia G, Boscaro M, Lumachi F, D'Amico DF. Role of bilateral adrenalectomy in Cushing's disease. World J Surg. 1994;18(4):462-6.

8. Kelly DF. Transsphenoidal surgery for Cushing's disease: a review of success rates, remission predictors, management of failed surgery, and Nelson's Syndrome. Neurosurg Focus. 2007;23(3):1-6.

9. Azad TD, Veeravagu A, Kumar S, Katznelson L. Nelson Syndrome: Update on Therapeutic Approaches. World Neurosurg. 2015;83(6):1135-40.

10. Patel J, Eloy JA, Liu JK. Nelson's syndrome: a review of the clinical manifestations, pathophysiology, and treatment strategies. Neurosurg Focus. 2015;38(2):E14.

11. Fountas A, Lim ES, Drake WM, Powlson AS, Gurnell M, Martin NM, et al. Outcomes of Patients with Nelson's Syndrome after Primary Treatment: A Multicenter Study from 13 UK Pituitary Centers. J ClinEndocrinolMetab. 2020;105(5):1527-37.

12. SOM230: a novel somatostatin peptidomimetic with broad somatotropin release inhibiting factor (SRIF) receptor binding and a unique antisecretory profile in: European Journal of Endocrinology Volume 146 Issue 5 (2002). [cited $2020 \mathrm{Jul}$ 7]. Available from: https://eje-bioscientifica-com.proxy.lib. umich.edu/view/journals/eje/146/5/707.xml?cited-by=yes\&legid=eje\%3 B146\%2F5\%2F707\&rss=1\&ssource $=m f$.

13. Schmid HA. Pasireotide (SOM230): Development, mechanism of action and potential applications. Mol Cell Endocrinol. 2008;286(1):69-74.

14. Colao A, Petersenn S, Newell-Price J, Findling JW, Gu F, Maldonado M, et al. A 12-Month Phase 3 Study of Pasireotide in Cushing's Disease. N Engl J Med. 2012;366(10):914-24.

15. Nelson DH, Meakin JW, Dealy JB, Matson DD, Emerson K, Thorn GW. ACTHProducing Tumor of the Pituitary Gland. N Engl J Med. 1958;259(4):161-4.

16. Jenkins PJ, Trainer PJ, Plowman PN, Shand WS, Grossman AB, Wass JA, et al. The long-term outcome after adrenalectomy and prophylactic pituitary radiotherapy in adrenocorticotropin-dependent Cushing's syndrome. J ClinEndocrinolMetab. 1995;80(1):165-71. 
17. Gil-Cárdenas A, Herrera MF, Díaz-Polanco A, Rios JM, Pantoja JP. Nelson's syndrome after bilateral adrenalectomy for Cushing's disease. Surgery. 2007; 141(2):147-52.

18. Sonino N, Zielezny M, Fava GA, Fallo F, Boscaro M. Risk factors and longterm outcome in pituitary-dependent Cushing's disease. $J$ ClinEndocrinolMetab. 1996;81(7):2647-52.

19. McCance DR, Russell CFJ, Kennedy TL, Hadden DR, Kennedy L, Atkinson AB. Bilateral adrenalectomy: low mortality and morbidity in Cushing's disease. ClinEndocrinol (Oxf). 1993;39(3):315-21.

20. Jornayvaz FR, Assie G, Bienvenu-Perrard M, Coste J, Guignat L, Bertherat J, et al. Pregnancy Does Not Accelerate Corticotroph Tumor Progression in Nelson's Syndrome. J ClinEndocrinolMetab. 2011;96(4):E658-62.

21. Thomas CG, Smith AT, Benson M, Griffith J. Nelson's syndrome after Cushing's disease in childhood: a continuing problem. Surgery. 1984;96(6):1067-77.

22. Imai T, Funahashi H, Tanaka Y, Tobinaga J, Wada M, Morita-Matsuyama T, et al. Adrenalectomy for Treatment of Cushing Syndrome: Results in 122 Patients and Long-Term Follow-up Studies. World J Surg. 1996;20(7):781-7.

23. Kemink L, Pieters G, Hermus A, Smals A, Kloppenborg P. Patient's age is a simple predictive factor for the development of Nelson's syndrome after total adrenalectomy for Cushing's disease. J ClinEndocrinolMetab. 1994;79(3):887-9.

24. Buchfelder M, Fahlbusch R, Adams EF, Kiesewetter F, Thierauf P. Proliferation Parameters for Pituitary Adenomas. In: Fahlbusch R, Bock WJ, Brock M, Buchfelder M, Klinger M, editors. Modern Neurosurgery of Meningiomas and Pituitary Adenomas. Vienna: Springer; 1996. p. 18-21. (Acta Neurochirurgica).

25. Lubke D, Saeger W, Ludecke DK. Proliferation Markers and EGF in ACTHSecreting Adenomas and Carcinomas of the Pituitary. EndocrPathol. 1995; 6(1):45-55.

26. Kasperlik-Załuska AA, Bonicki W, Jeske W, Janik J, Zgliczyński W, Czernicki Z Nelson's Syndrome - 46 Years Later: Clinical Experience with 37 Patients. ZentralblattFürNeurochir. 2006;67(01):14-20.

27. Pollock BE, Young WF. Stereotactic radiosurgery for patients with ACTHproducing pituitary adenomas after prior adrenalectomy. Int J RadiatOncol. 2002:54(3):839-41.

28. Moore TJ, Dluhy RG, Williams GH, Cain JP. Nelson's Syndrome: Frequency, Prognosis, and Effect of Prior Pituitary Irradiation. Ann Intern Med. 1976; 85(6):731-4

29. Barber TM, Adams E, Ansorge O, Byrne JV, Karavitaki N, Wass JAH. Nelson's syndrome. Eur J Endocrinol. 2010;163(4):495-507.

30. Jane JA, Vance ML, Woodburn CJ, Laws ER. Stereotactic radiosurgery for hypersecreting pituitary tumors: part of a multimodality approach. Neurosurg Focus. 2003;14(5):1-5.

31. Marek J, Ježková J, Hána V, Kršek M, Liščák R, Vladyka V, et al. Gamma knife radiosurgery for Cushing's disease and Nelson's syndrome. Pituitary. 2015; 18(3):376-84.

32. Caruso JP, Patibandla MR, Xu Z, Vance ML, Sheehan JP. A Long-Term Study of the Treatment of Nelson's Syndrome With Gamma Knife Radiosurgery. Neurosurgery. 2018;83(3):430-6

33. Vik-Mo EO, Øksnes M, Pedersen P-H, Wentzel-Larsen T, Rødahl E, Thorsen F, et al. Gamma knife stereotactic radiosurgery of Nelson syndrome. Eur J Endocrinol. 2009;160(2):143-8.

34. Wilson PJ, Williams JR, Smee RI. Nelson's syndrome: single centre experience using the linear accelerator (LINAC) for stereotactic radiosurgery and fractionated stereotactic radiotherapy. J ClinNeurosci Off J NeurosurgSocAustralas. 2014:21(9):1520-4

35. Mauermann WJ, Sheehan JP, Chernavvsky DR, Laws ER, Steiner L, Vance ML. Gamma Knife surgery for adrenocorticotropic hormone-producing pituitary adenomas after bilateral adrenalectomy. J Neurosurg. 2007;106(6):988-93.

36. Tommasi CD, Vance ML, Okonkwo DO, Diallo A, Laws ER. Surgical management of adrenocorticotropic hormone-secreting macroadenomas: outcome and challenges in patients with Cushing's disease or Nelson's syndrome. J Neurosurg. 2005;103(5):825-30.

37. Kemink SAG, Grotenhuis JA, Vries JD, Pieters GFFM, Hermus ARMM, Smals AGH. Management of Nelson's syndrome: observations in fifteen patients. ClinEndocrinol. 2001;54(1):45-52.

38. Kelly PA, Samandouras G, Grossman AB, Afshar F, Besser GM, Jenkins PJ. Neurosurgical treatment of Nelson's syndrome. J ClinEndocrinolMetab. 2002; 87(12):5465-9.

39. Banasiak MJ, Malek AR. Nelson syndrome: comprehensive review of pathophysiology, diagnosis, and management. Neurosurg Focus. 2007;23(3): $1-10$
40. Xing B, Ren Z, Su C, Wang R, Yang Y, Hu Y. Microsurgical treatment of Nelson's syndrome. Chin Med J (Engl). 2002;115(8):1150-2.

41. Shraga-Slutzky I, Shimon I, Weinshtein R. Clinical and biochemical stabilization of Nelson's syndrome with long-term low-dose cabergoline treatment. Pituitary. 2006;9(2):151-4.

42. Casulari LA, Naves LA, Mello PA, Neto AP, Papadia C. Nelson's Syndrome: Complete Remission with Cabergoline but Not with Bromocriptine or Cyproheptadine Treatment. Horm Res Paediatr. 2004;62(6):300-5.

43. Pivonello R, Faggiano A, Di Salle F, Filippella M, Lombardi G, Colao A. Complete remission of Nelson's syndrome after 1-year treatment with cabergoline. J Endocrinol Invest. 1999:22(11):860-5.

44. Moyes VJ, Alusi G, Sabin HI, Evanson J, Berney DM, Kovacs K, et al. Treatment of Nelson's syndrome with temozolomide. Eur J Endocrinol. 2009;160(1):115-9.

45. Kurowska M, Nowakowski A, Zieliński G, Malicka J, Tarach JS, Maksymowicz $M$, et al. Temozolomide-Induced Shrinkage of Invasive Pituitary Adenoma in Patient with Nelson's Syndrome: A Case Report and Review of the Literature [Internet]. Vol. 2015, Case Reports in Endocrinology. Hindawi; 2015 [cited $2020 \mathrm{Jul}$ 8]. p. e623092. Available from: https://www.hindawi.com/journals/ crie/2015/623092/

46. Mullan KR, Leslie H, McCance DR, Sheridan B, Atkinson AB. The PPARgamma activator rosiglitazone fails to lower plasma ACTH levels in patients with Nelson's syndrome. ClinEndocrinol (Oxf). 2006;64(5):519-22.

47. Kreutzer J, Jeske I, Hofmann B, Blumcke I, Fahlbusch R, Buchfelder M, et al. No effect of the PPAR-gamma agonist rosiglitazone on ACTH or cortisol secretion in Nelson's syndrome and Cushing's disease in vitro and in vivo. ClinNeuropathol. 2009;28(6):430-9.

48. Munir A, Song F, Ince P, Walters SJ, Ross R, Newell-Price J. Ineffectiveness of Rosiglitazone Therapy in Nelson's Syndrome. J ClinEndocrinolMetab. 2007; 92(5):1758-63.

49. Kelly W, Adams JE, Laing I, Longson D, Davies D. Long-term treatment of Nelson's syndrome with sodium valproate. ClinEndocrinol (Oxf). 1988;28(2): 195-204.

50. Dornhorst A, Jenkins JS, Lamberts SW, Abraham RR, Wynn V, Beckford U, et al. The evaluation of sodium valproate in the treatment of Nelson's syndrome. J ClinEndocrinolMetab. 1983;56(5):985-91.

51. Tyrrell JB, Lorenzi M, Gerich JE, Forsham PH. Inhibition by somatostatin of ACTH secretion in Nelson's syndrome. J ClinEndocrinolMetab. 1975;40(6): 1125-7.

52. Arregger AL, Cardoso EML, Sandoval OB, MonardesTumilasci EG, Sanchez R, Contreras LN. Hormonal secretion and quality of life in Nelson syndrome and Cushing disease after long acting repeatable octreotide: a short series and update. Am J Ther. 2014;21(4):e110-116.

53. Petrini L, Gasperi M, Pilosu R, Marcello A, Martino E. Long-term treatment of Nelson's syndrome by octreotide: A case report. J Endocrinol Invest. 1994; 17(2):135-9.

54. Kelestimur F, Utas C, Ozbakir O, Selçuklu A, Kandemir O, Ozcan N. The effects of octreotide in a patient with Nelson's syndrome. Postgrad Med J. 1996;72(843):53-4.

55. Katznelson L. Sustained Improvements in Plasma ACTH and Clinical Status in a Patient With Nelson's Syndrome Treated With Pasireotide LAR, a MultireceptorSomatostatin Analog. J ClinEndocrinolMetab. 2013;98(5):1803-7.

56. Batista DL, Zhang X, Gejman R, Ansell PJ, Zhou Y, Johnson SA, et al. The effects of SOM230 on cell proliferation and adrenocorticotropin secretion in human corticotroph pituitary adenomas. J ClinEndocrinolMetab. 2006;91(11): 4482-8

57. Pedroncelli AM. Medical Treatment of Cushing's Disease: Somatostatin Analogues and Pasireotide. Neuroendocrinology. 2010;92(Suppl. 1):120-4.

58. Daniel E, Debono M, Caunt S, Girio-Fragkoulakis C, Walters SJ, Akker SA, et al. A prospective longitudinal study of Pasireotide in Nelson's syndrome. Pituitary. 2018;21(3):247-55.

\section{Publisher's Note}

Springer Nature remains neutral with regard to jurisdictional claims in published maps and institutional affiliations. 